\title{
APPLYING FLOWER WRITING STRATEGY TO THE TENTH GRADERS IN WRITING DESCRIPTIVE TEXT
}

\author{
By: \\ Yuliana \\ English Language Education Study Program at FKIP Islamic University of Ogan Komering Ilir \\ Kayuagung, South Sumatera \\ Yuliana190@yahoo.com \\ Rachmanita \\ English Language Education Study Program at FKIP Islamic University of Ogan Komering Ilir \\ Kayuagung, South Sumatera \\ Ayuksulung2407@gmail.com
}

\begin{abstract}
Writing is regarded as a challenging subject in school. At the same time, it was a critical skill for students to master because it is so important in this age of globalization. This study aimed to find out whether or not the Flower Writing Strategy was effective to be used in teaching writing descriptive text. The quasi-experimental method was used in this study. The sample of the study was 68 students taken by using the purposive sampling technique. The data was gained by using a written test. The data were analyzed by using a t-test. Based on the result of the independent sample t-test, it was found that t-obtained (3.439) was higher than table (1.9955) and $p_{\text {value }}(0.001)$ was less than óvalue $(0.05)$. It meant that the null hypothesis (Ho) was rejected and alternative hypothesis (Ha) were accepted. Hence, Flower Writing Strategy was effective to be used in teaching descriptive text.
\end{abstract}

Keywords: flower writing strategy, students' achievement, writing

\section{INTRODUCTION}

Nowadays, most students used

writing to communicate in this new

era by using modern technologies,

such as E-mail, fast text messages on

cell phones, and social media

chatting. Students could think and

write down their ideas in written form

to do communications. Thus, writing is an important skill to help students

to communicate with each other. By writing, students could share their ideas and information by communicating ideas into a paper or typing in social media. It meant that writing was a tool to convey concepts, emotions, and opinions to the reader. Harlena (2019) clarifies 
that writing could give the reader knowledge or information. It meant that students could share or offer information or knowledge through writing.

Harmer (2010) describes that writing has always been a part of the curriculum in teaching English. Writing skill was considered the most difficult language skill to learn, but it was also the most necessary for students to master. By teaching writing, it helped students to deliver some messages and also integrating with other skills. Besides, writing was useful to improve students thinking skills (Graham \& Sandmel, 2011). It meant that writing is an important English skill that should be learned by every language learner.

Even though writing has become increasingly essential in the digital era, students have struggled to do so. Writing is regarded as a tough task. After years of studying English, many high school students struggle to develop their writing skills (Novia \& Saptarina, 2020). Many of themhad the problem in writing. First, some students were not interested in it. They often think that writing especially in a foreign language was a difficult and complicated process (Ho \& Trinh, 2019). Second, they had difficulties starting writing. They could not think or imagine the main ideas or topic that they want to construct to be a paragraph. They could not find the interesting topic and supporting details to make a complete paragraph. As the result, they were often giving up before they do the task. Sheir et al., (2015) classify that many students lacked basic knowledge about how to approach writing and the writing 
process. It meant that the students did not know the structure of the text. They did not know how to make paragraphs based on the structure of the text.

The descriptive text was found the most in the student's textbook start from the seventh grade up to the tenth. It was the kind of text that the writer describes something, place, or people. Saraswati et al., (2018) describe that a descriptive text was one of the types of writing where the writer describing something which is commonly a person or a place. Further, (Jayanti, 2019) defines that descriptive describes how something appears, feels, smells, tastes, and sounds. It meant that descriptive text was the text that explained something. A descriptive text was often used to create a vivid image of people, locations, and events in all types of writing. It was usually used to describe something specific so that the reader can imagine and know exactly about the things that were described. It can be inferred that a descriptive text was used to describe specific people, locations, or objects.

There were some problems in writing descriptive text. (Fitriani et al. (2019) define that many students found it hard to start writing especially in a foreign language. Moreover, Kirana et al., (2018) describe that since they did not know how to efficiently generate and organize theirthoughts, many students struggled to compose descriptive text. They did not understand the basic structure of the descriptive text, to put it that way. Further, Husna (2013) mentions that writing a descriptive text was 
challenging for students. The first complete paragraph. One of the dealt with lower-level skills such as strategies that a teacher could use to handwriting, spelling, and grammar. evaluate a student's writing abilities The second issue was on a higher and teach them how to write a good level, such as concept generation and text series was the Flower Writing topic selection, preparation, Strategy. It was a straight forward and production, or organization, and text engaging strategy to use in the revision.

classroom.

Therefore, Flower Writing Strategy could be used as an alternative to improve students' writing skills. The Flower Writing Strategy was a writing strategy for helping students to enhance their writing skills, especially in paragraph writing. Kasmaini et al., (2019) explain that Flower Writing was a writing strategy in which the central (main) idea was written first, followed by the information that surrounded it. The details had connections or relations with the main idea to make a

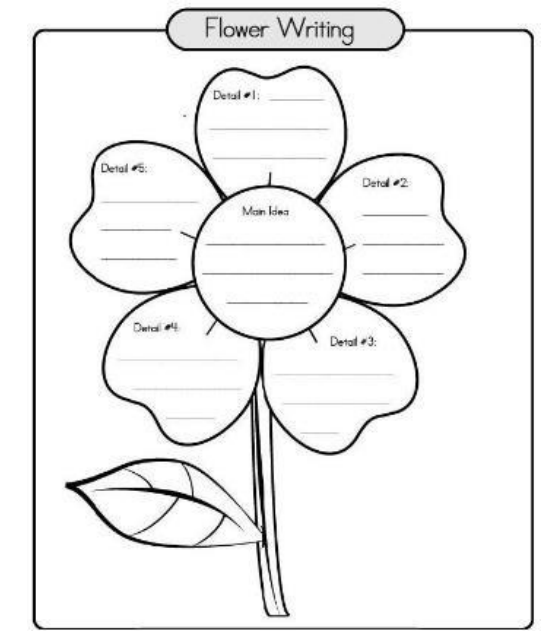

The Example of Flower Writing Strategy

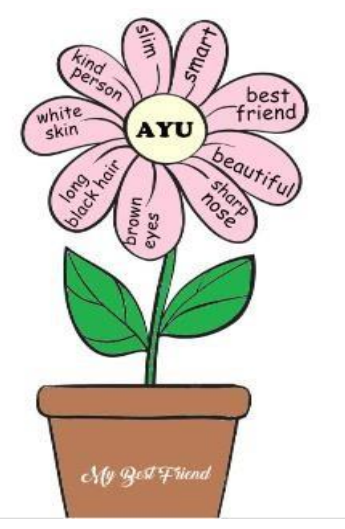


Based on the above, it can be achievement is largely similar. derived that the flower writing Flipping the coin was used to decide strategy is supposed to serve as a which one would be the experiment guide for students in constructing a class and which would be the control text or essay using the steps and class. As a result, the experimental points outlined in the strategy. It is group was assigned X.3 class, while reasonable to expect that students' the control group was assigned X.4 writing skills will develop as a result class. of this strategy.

Students who were taught the Flower Writing Strategy were given a

\section{METHODOLOGY}

The quasi-experimental method was used to carry out this investigation. The participants in this study were all 247 students in tenth grade at SMA Negeri I Tanjung Lubuk. The sample was chosen by using the purposive sampling technique, which means a set of criteria is used to choose the sample. First, they have some total numbers. Second, they had the same English teacher as well. The last, their English written test to collect data on their writing achievement. Therefore, the test was in the form of an essay. In this study, a written essay was measured students writing achievement.

In this study, inter-rater reliability was applied. Two raters gave the score of the test using a descriptive text rubric. The raters had experience as an English teacher for 5 years and get an S1 degree. The reliability coefficient of the test was 
0.939. It was higher than 0.70. It means that the test was reliable. To assess the test's validity, content validity was used in which the table of specification of test was made based on the writing syllabus.

The data were analyzed using a t-test to see whether there was a significant difference in students' achievement between those who were taught using the Flower Strategy in descriptive text and those who were not. The paired sample t-test was used to examine the data between the classes. An independent sample t-test was used to determine if there was a significant difference between the groups (experimental and control groups) to determine the results.

In teaching writing by using Flower Writing Strategy, Jacobson, Johnson, and Lapp (2011, p.93) mention six steps of this strategy explained as follows.

1. Selected appropriate material which is related to the lesson.

2. Introduced each component of writing pieces (the pistil or center of the flower and the petal around the flower) by using the flower graphic organizer.

3. The class discussed the text's problem structure, including the main idea/introduction (the topic to be described), detail (all supporting sentences explain the topic), and transition phrase.

4. The instructor gave a sample writing piece for students to model work from formulating a thesis statement to the general topic areas that the students would use to help their stance 
when implementing the treatment using Flower Writing technique first.

Strategy.

5. Students used the flower graphic organizer created by the instructor to prepare the piece and ensure all of the elements.

6. Students followed the steps outlined in the plan to write the essay.

Table 1

The Statistical Analysis of Experimental Group

\begin{tabular}{ccccc}
\hline $\mathbf{t}_{\text {obt }}$ & df & $\begin{array}{c}\text { Sig. } \\
\mathbf{2} \\
\text { tailed }\end{array}$ & $\begin{array}{c}\text { Mean } \\
\text { Difference }\end{array}$ & $\mathbf{t}_{\text {table }}$ \\
\cline { 1 - 3 } & $\underline{34}$ & $\underline{.000}$ & $\underline{12.357}$ & $\underline{2.0322}$ \\
\hline
\end{tabular}

The improvement happened since the students already had a guide to write a good paragraph. They felt free to write whatever they wanted by

\section{RESULT AND DISCUSSION}

From the result of the pretest and posttest in the experimental group, it was found that the student's mean difference was 12.357 with $\mathrm{t}_{\text {obtained }}$ was 7.883 at the significant level of $p<0.05$ in two-tailed testing with $\mathrm{df}=34$. Since the value of $\mathrm{t}_{\text {obtained }}$ (7.883) was higher than the critical value of table (2.0322) and p palue (0.000) was lower than $a_{\text {value }}(0.05)$, it meant that students' achievement in writing was improved after giving using the Flower writing strategy because they did not have to worry about making mistakes. They were free to write down something, anywhere, or any occurrence that came to mind, and then added supporting information to build the main idea. Those activities made students very excited to do the writing.

While in the control group, the result showed that the mean difference between pretest and 
posttest in the control group was 5.8571, $\mathrm{t}_{\text {obtained }}$ was 5.426. Since the value of $t_{\text {obtained }}$ (5.426) was higher than the critical value of $t_{\text {table }}(2.0322)$ and $p_{\text {value }}(0.000)$ was lower than $a_{\text {value }}$ (0.05), it meant that students' achievement in writing also improved after giving treatment using conventional way. This was because many students in the control group attended English courses after school.

Furthermore, some of them also

actively joined English competitions.

Those were assumed as the factors

that influencing the score.

Table 2

The Statistical Analysis of Control Group

\begin{tabular}{ccccc}
\hline $\mathbf{t}_{\text {obt }}$ & df & $\begin{array}{c}\text { Sig. } \\
(\mathbf{2} \\
\text { tailed }\end{array}$ & $\begin{array}{c}\text { Mean } \\
\text { Difference }\end{array}$ & $\mathbf{t}_{\text {table }}$ \\
& $\underline{5.426}$ & $\underline{.000}$ & $\underline{5.857}$ & $\underline{2.0322}$ \\
\hline
\end{tabular}

Based on the independent samples test, the $\mathrm{t}_{\text {obtained }}$ was 3.439 at a significant level $\mathrm{p}<0.05$ and the degree of freedom (df) 68. The critical value of $t_{\text {table }}$ was 1.9955 . since the value of $t_{\text {obtained }}$ (3.439) was higher than the value of $t_{\text {table }}(1.9955)$ and $p_{\text {value }}(0.001)$ was lower than $a_{\text {value }}$ (0.05), the null hypothesis was rejected and the alternative hypothesis was accepted. Therefore, Flower Writing Strategy was found to be successful in improving students' descriptive text writing skills.

Table 3

The Comparison of Statistical Analysis Between Experimental and Control Groups

\begin{tabular}{ccccc}
\hline $\mathbf{t}_{\text {obt }}$ & $\mathbf{d f}$ & $\begin{array}{c}\text { Sig. } \\
\mathbf{2} \\
\text { tailed }\end{array}$ & $\begin{array}{c}\text { Mean } \\
\text { Difference }\end{array}$ & $\mathbf{t}_{\text {table }}$ \\
3.439 & 68 & .001 & 8.285 & 1.9955 \\
\hline
\end{tabular}

Although the control group's results showed a significant difference, the experimental group's score was significantly higher than the control group's. The mean difference between each group confirms that the experimental group's mean score was higher than 
the control group's (see Tables 1 and 2).

Since this strategy was inspired by flower petals, it was simple to implement. This strategy allowed space for the key concepts to be written in the document as well as space for supporting details to be placed around it. The students were guided to find the main ideas first, and then determine the supporting detail that related to the main ideas. By using this strategy students were guided very carefully to make a paragraph.

They could write whatever things come to their mind as the main idea then describe it by giving the details. This strategy made the students becoming more creative and could avoid anxiety and boredom in learning to write. Because they were free to choose the thing that they wanted to write about such as about their beloved pets, their favorite actor, favorite food, and so on. After they found the thing that they want to write they just put some detailed words to explain a thing.

This was in line with Wati (2019) who stated that the flower writing strategy was a simple writing technique that could be used at any stage. Moreover, this strategy can be used in a group or on an individual basis. This strategy will encourage students to think creatively to come up with a subject and supporting details for an essay. Finally, the flower writing strategy presented several simple guidelines to assist students in writing paragraphs.

\section{CONCLUSION}

The result of the experimental study showed that 
two groups (experimental and control) of students who received two different techniques of teaching writing were all making significant progress in their writing skills. Although the experimental group's ability to write descriptive text was better than that of the control group. It can be seen from the mean difference of pre and posttest of the experimental group.

It can be summarized that the

Flower Writing Strategy was effective for teaching tenth-grade students at SMA Negeri 1 Tanjung

Lubuk to write descriptive texts.

\section{REFERENCES}

Fitriani, F., Nur, R. H., Bustamin, B., Ali, S. M., \& Nurisman, N. (2019). Improving students' descriptive text writing by using writing in the here and now strategy at the tenth grade students of vocational high school. International Journal for Educational and Vocational Studies, 1(6), 632-636. Https://doi.org/10.29103/ijevs.v1i6 .1802

Graham, S., \& Sandmel, K. (2011). The process writing approach: A metaanalysis. Journal of Educational Research, 104(6), 396-407. Https://doi.org/10.1080/00220671.20 10.488703

Harlena, D. (2019). Collaborative writing strategy for teaching writing descriptive text. International journal of scientific \& technology research, 8(10), 3316-3318. Www.ijstr.org

Harmer, J. (2010). How to teach english with DVD. Aviagen: Pearson Education.

Ho, P. V. P., \& Trinh, D. T. P. (2019). High school students' common errors in writing essays. International Journal of English Linguistics, 9(6), 309.

Https://doi.org/10.5539/ijel.v9n6p30

Husna, L. (2013). An analysis of students' writing skill in descriptive text at grade X1 IPA of MAN 2 Padang. Journal Ilmiah Pendidikan Scholastic, 1(1), 16-28.

Jayanti, A. D. (2019). Students' writing ability on English descriptive text at grade VIII in SMPN 33 Padang. English Franca: Academic Journal of English Language and Education, 3(1), 71-93.

Kasmaini, Sofyan, D., \& Zahrida. (2019). Penerapan strategi flower writing untuk meningkatkan kemampuan menulis penerapan strategi flower writing untuk meningkatkan kemampuan menulis mahasiswa semester III Program Studi S-1 Pendidikan Bahasa Inggris FKIP Universitas Bengkulu. Prosiding Seminar Nasional Bulan Bahasa (Semiba) 2019, 144-153.

Kirana, E., Syarif, H., \& Anwar, D. (2018). Students' writing ability in descriptive texts and their problems of using appropriate adjective in SMP. International Conferences on Education, Social Sciences and 
Technology, $508-513$.

Https://doi.org/10.29210/2018174

Novia, F., \& Saptarina, E. (2020).

Process Writing Approach (PWA):

The Correlation between Students Writing Attitude and Writing Achievement Fitri. 4th Sriwijaya University Learning and Education International Conference (SULEIC 2020) Process, 513, 331-336. Https://doi.org/10.2991/assehr.k.20 1230.127

Saraswati, D. D., Yunus, M., \& Fiftinova. (2018). Improving descriptive text writing achievement by using power strategy. The Journal of English Literacy Education, 5(2), 144-157.

Sheir, A., Zahran, F., \& Koura, A. (2015). The effectiveness of process writing approach in developing EFL writing performance of ESP college students. Educations Sciences Journal, 1-23.

Wati, M. S. A. (2019). A comparative study between quick write and flower writing strategies toward writing skills of the seventh grade students of MTS N 1 Salatiga in the academic year of 2019/202. Unpublished: IAIN Salatiga. 